\title{
One Step Closer to Mental Health Parity
}

\section{Lorraine Schmall*}

\section{INTRODUCTION}

Elijah, a powerful prophet in the Old Testament, suffered despair and depression. ${ }^{1}$ He prayed for death: "It is enough; now, O LORD, take away my life; for I [am] not better than my fathers." ${ }^{2}$ He was neither the first nor the last to have a mental illness. ${ }^{3}$ The estimates for the incidence of some type of mental illness in the United States are remarkably high: approximately one in four. ${ }^{4}$ A few millennia after Elijah, people with emotional problems fortunate enough to participate in the workforce have two potential bulwarks against suf-

* Professor of Law, Northern Illinois University College of Law. Special thanks to Amanda Adams, Lisa Hoebing, Sarah Moczydlowski, Lori Scardina, and Emily Schmall for their research, editing, and production assistance; and to NIU Dean Malcolm Morris, for supporting this work.

11 Kings 19:1-8 (King James). Elijah has been considered the "loftiest and most wonderful prophet of the Old Testament." See Charles L. Souvay, Elias, in 5 The CAtholic EncycloPEDIA 381 (1909), available at http:/www.newadvent.org/cathen/05381b.html. Even those who follow the Baha'i tradition revere Elijah as one of the most important ancient prophets. Simon Griver, The Baha'i Gardens, http://www.jewishvirtuallibrary.org/jsource/Society_ \&_Culture/bahaig.html (last visited June 30, 2009).

2 Kings 19:4 (King James).

3 See generally Mental Health Client Action Network, http://www.mhcan.org/index.html (last visited June 30, 2009). The Mental Health Client Action Network (MHCAN) is a "peer run, self-help, drop-in center where people with psychiatric disabilities can congregate and socialize in a safe place, free from the stigma of mental illness imposed by society," and maintains a website called "Famous Crazy Folks." Id. (follow "Resources" hyperlink; then follow "Famous Crazy Folks - We are not alone" hyperlink). Among those listed are: Winston Churchill, English Wartime Prime Minister; Alexander Hamilton, a drafter of the Declaration of Independence; Copernicus, scientist; Charles Darwin, biologist; Kay Jamison, professor and writer; Abraham Lincoln, U.S. President; Martin Luther, religious leader; Michelangelo, artist; Napoleon, French Emperor and general; Nebuchadnezzar, king; Lord Nelson, statesman; Theodore Roethke, poet; Ted Turner, entrepreneur; Mike Wallace, investigative reporter; Emile Zola, writer. Id. According to the site, "[a]lmost no one was 'Glad' to be their friend until they became famous." Id.

${ }^{4}$ Nat'l Inst. of Mental Health (NIMH), The Numbers Count: Mental Disorders in America (2008), http://www.nimh.nih.gov/health/publications/the-numbers-count-mental-disordersin-america.shtml (describing the prevalence of mental disorders in America). According to the National Institute of Mental Health (NIMH), "[a]n estimated 26.2\% of Americans ages 18 and older . . . suffer from a diagnosable mental disorder in a given year." Id. Based on the "2004 U.S. Census Bureau residential population estimate . . . this figure translates to 57.7 million people." Id. NIMH has also found that "[e]ven though mental disorders are widespread in the population, the main burden of illness is concentrated in a much smaller proportion-about 6 percent, or one in 17-who suffer from a serious mental illness." Id. Furthermore, NIMH claims, "mental disorders are the leading cause of disability in the U.S. and Canada for ages 15 to 44." Id. 
fering the pain described by the ancient prophet: antidiscrimination protection under the Americans with Disabilities Act ("ADA") 5 and health insurance. However, the ADA has not been effective in mitigating the effects of discrimination upon the mentally ill, and health insurance coverage has been both discriminatory and deficient. Insurance plans and policies offer less coverage and more limits on the mentally ill than on any other patients, ${ }^{6}$ and companies almost never accommodate mental illness or tolerate the symptoms of those diseases. ${ }^{7}$ Congress tried to address these shortcomings through the proposed Mental Health Parity Act of $2007,{ }^{8}$ an amendment to the Employee Retirement Income Security Act ("ERISA"), ${ }^{9}$ the federal law that regulates most employee benefits, to little avail. ${ }^{10}$ In the meantime, the Supreme Court made it more

5 The Americans with Disabilities Act purports to protect people with "physical or mental" impairment. 42 U.S.C. $§ 12102(1)(A)$ (2006).

${ }^{6}$ Rogers v. Dep't of Health \& Envtl. Control, 174 F.3d 431, 435-36 (4th Cir. 1999) ("Insurers have historically and consistently made distinctions between mental and physical illness in offering health and disability coverage"). See also Group Insurance 442 (William F. Bluhm et al. eds., 2d ed. 1996) ("Most LTD [long-term disability] plans impose a lifetime limit of 24 months on benefits for disabilities due to mental and nervous conditions when not confined to an institution.”); U.S. Equal Employment OpPortunity Comm'n, InTERim Enforcement Guidance in the Application of the ADA to Disability-Based ProviSions of Employer-Provided Health Insurance 6 (1993), http://www.eeoc.gov/policy/ docs/guidance.pdf ("Typically, a lower level of benefits is provided for the treatment of mental/nervous conditions than is provided for the treatment of physical conditions."). A recent article in the American Medical News reports, "Many plans, for example, require more prior authorizations or higher patient cost-sharing for mental health benefits than they do for medical or surgical benefits." Doug Trapp, Mental Health Coverage to See Boost as Long-Sought Parity Law is Enacted, available at http://www.ama-assn.org/amednews/2008/ 10/27/gvl11027.htm (reporting a new law that should improve mental health benefits by requiring parity with physical health benefits).

7 For a comparable discussion in the United Kingdom, see Roy SAInSBURy ET AL., DeP'T for Work \& Pensions, Research Report No. 513, Mental Health and Employment (2008). See also Criado v. IBM Corp., 145 F.3d 437, 443 (1st Cir. 1998) ("Criado's physician testified that if given a significant leave she could adjust to her situation and after he experimented with medication she might return to her previous level of functionality. This evidence indicates that with a reasonable accommodation Criado could perform the essential functions of her job.”).

8 Mental Health Parity Act of 2007, S. Res. 558, 110th Cong. (2007). The bill was introduced on February 12, 2007, and passed by the Senate on September 18, 2007, but died when the House did not vote on the bill before the session term expired. See id.; 153 Cong. REc. S1864-65 (daily ed. Feb. 12, 2007); GovTrack.us, S.558: Mental Health Parity Act of 2007, http://www.govtrack.us/congress/bill.xpd?bill=s110-558 (last visited June 30, 2009); see also 153 Cong. Rec. S1864-65 (daily ed. Feb. 12, 2007) (statements of Sens. Domenici and Kennedy explaining the exploited loopholes of the Mental Health Parity Act ("MHPA") of 1996 and the intended effects of the MHPA 2007).

9 Employee Retirement Income Security Act (ERISA), 29 U.S.C. $§$ 1001-1461 (2006).

10 ERISA, passed in 1974, created procedural controls of all employee benefit plans and exempted such plans from state control over the creation and administration of benefits. Id. Firms with sufficient cash reserves or credit can self-insure their employees' medical risks and avoid state mandates and state taxes on premiums. See Timothy Stoltzfus Jost, Disentitlement? The Threats Facing our Public Health-Care Programs and a RightsBased Response 185 (2003). See generally Mansel G. Blackford, A History of Small Business IN AMERICA (2d ed. 2003) (contending that most US governmental policies further the interests of "big" business). 
difficult for those with mental illness to fit within the ADA's protections. ${ }^{11}$

However, important changes to these laws could significantly improve the lives of the mentally ill. On September 25, 2008, President George W. Bush signed the Americans with Disabilities Act Amendments Act ("ADAAA") into law. ${ }^{12}$ Less than one month later, mental health parity in employer-provided health insurance became a federal mandate when the Paul Wellstone and Pete Domenici Mental Health and Addiction Equity Act of 2008 ("Wellstone Act") ${ }^{13}$ was quietly enacted as part of the congressional economic bailout. ${ }^{14}$ The aforementioned new laws might actually bring society one step closer towards ending discrimination against the mentally ill. ${ }^{15}$

At a time when the Obama presidency is framing the social issues for the next half-decade, and when a woman accepted the Republican vice-presidential nomination moments before cradling her special needs infant in her arms, mental health is ever-present in the news. That is atypical. In over a dozen years, no significant legislation nor federal agency has focused on the problems

11 See infra section II.A; see also Littleton v. Wal-Mart Stores, Inc., 231 F. App'x 874, 8768 (11th Cir. 2007) (finding plaintiff, who was diagnosed with intellectual and developmental disorders, not to be disabled under the ADA); Rohan v. Networks Presentations LLC, 375 F.3d 266, 273-78 (4th Cir. 2004) (finding plaintiff, who was diagnosed with post-traumatic stress disorder, was not disabled as defined by the ADA); Johnson v. N.C. Dep't of Health \& Human Servs., 454 F. Supp. 2d 467, 473-74 (M.D.N.C. 2006) (finding that plaintiff diagnosed with bipolar disorder was not considered disabled under the ADA); McMullin v. Ashcroft, 337 F. Supp. 2d 1281, 1294-99 (D. Wyo. 2004) (finding that plaintiff diagnosed with depression was not considered disabled under the ADA).

12 ADA Amendments Act of 2008, Pub. L. No. 110-325, 122 Stat. 3553.

13 H.R. 1424, 110th Cong. § 512 (2008) (enacted).

14 Emergency Economic Stabilization Act of 2008, Pub. L. No. 110-343, 122 Stat. 3765, 3881.

15 Since most people obtain insurance as an ancillary benefit of employment, as unemployment has risen, the number of uninsured individuals has also risen. CARMEN DeNavasWalt, Bernadette D. Proctor \& Cheryl Hill Lee, U.S. Census Bureau, Income, Poverty, and Health Insurance Coverage in the United States: 2005, at 20-23 (2006), http://www.census.gov/prod/2006pubs/p60-231.pdf. In 2005, there were 46,577,000 people uninsured. Id. at 22 tbl.8. Of those, over 21,000,000 worked full-time. Id. Nearly onefourth of the United States' workforce is contingent or part-time, and only about twenty percent of those employees have health insurance. Most Temp, Part-Time Workers Lack Job-Linked Health Insurance, MedicineOnline, Dec. 1, 2005, http://www.medicineonline. com/news/10/6951/Most-Temp-Part-Time-Workers-Lack-Job-Linked-Health-Insurance.html ("Only 21 percent of the 34 million part-time, temporary and contract workers in the United States have [employer-provided] health insurance, compared with 74 percent of regular, fulltime workers. ... '[Such widespread]non-traditional work arrangements, [require] new strategies for affordable, comprehensive benefits,' [Commonwealth Fund President Karen] Davis said."). Firms that employ high proportions of female workers, part-time workers, and seasonal workers "are known to offer health insurance less often, and when they offer it, they are less likely to offer generous benefits." Gail A. Jensen, Employer Choice of Wage SupPlements 35-37 (1986). Besides gender discrimination, which crosses all race and color lines, significantly higher numbers of other minorities are uninsured. DeNavas-WaLt, Proctor \& LeE, supra, at 21. In 2005, the uninsured rates for non-Hispanic Whites at $11.3 \%$ and for Blacks at $19.6 \%$ were not statistically different from 2004 . Id. at 21 . The rate for Asians increased to $17.9 \%$ in 2005 , from $16.5 \%$ in 2004, but the 2005 rate was not statistically different from 2004. Id . at 22 tbl 8. Among Hispanics, the uninsured rate was statistically unchanged at $32.7 \%$, while the number of Hispanics without coverage increased from 13.5 million in 2004 to 14.1 million in 2005. Id. at 21. 
associated with mental health since David Satcher, former President Bill Clinton's Surgeon General, reported glaring disparities that violated not only civil rights, but best medical and management practices. ${ }^{16}$ Until now, mental illness demonstrated an almost irreconcilable conflict between economy and shame, made even worse by stereotypical thinking that stigmatizes the mentally ill or impaired. "Treating people differently on the basis of mental illness does not provoke the same moral outrage as that inspired by differential treatment on the basis of race, sex, or even physical disability." 17

Society's reluctance to treat individuals with mental illness with equality leads to the loss of talents and makes it far more challenging for these individuals to contribute their accomplished skills to society. This loss is simply inefficient and unjust. Moreover, the spillover into the lives of families, co-workers, and communities is harsh. ${ }^{18}$ Although not representing a solution to the problem that half of our population is uninsured, the ADAAA and Wellstone Act might actually bring us one step closer to mental health parity in the United States.

This Article examines these two new laws. Part II provides a brief background on the ADA and describes the amendments to it in the ADAAA. Part III describes the Wellstone Act. Part IV discusses positive effects the new laws could have on easing stereotypes, lowering employer costs, and living in an ethically better society.

\section{The Americans with Disabilities Amendments Act of 2008 And the New Meaning of Disability}

\section{A. Overview of the ADA}

Congress passed the ADA in 1990, with the intent of creating a civil rights law to protect people with disabilities from discrimination based on disabil-

16 David Satcher, Preface from the Surgeon General, in U.S. Public Health Serv., Dep't of Health \& Human Servs., Mental Health: A Report of the Surgeon General (1999), http://www.surgeongeneral.gov/library/mentalhealth/home.html (containing the statement of the Surgeon General referring generally to inadequate mental health benefits). 17 Elizabeth F. Emens, The Sympathetic Discriminator: Mental Illness, Hedonic Costs, and the ADA, 94 Geo. L.J. 399, 401 (2006) ("Mental illness tends to produce . . . 'hedonic costs' - an increase in negative emotions or a loss of positive emotions - in people with mental illness. And the hedonic costs of an individual's mental illness may create hedonic costs for nearby others.").

18 According to Michael Faenza, President of the National Mental Health Association, an advocacy organization for patients and professionals: "[T]he bottom line is that people with mental illnesses are the last [remaining] class of American citizens that are blatantly discriminated against in any social institution." Of Sound Mind and Body (PBS television broadcast May 9, 1996) (transcript available at http://www.pbs.org/newshour/bb/health/may96/ mental_health_5-9.html). See Mathew G. Simon, Not All Illnesses are Treated EquallyDoes a Disability Benefits Plan Violate the ADA by Providing Less Generous Long-Term Benefits for Mentally Disabled Employees than for Physically Disabled Employees?, 8 U. PA. J. LAв. \& Emp. L. 943, 976 (2006); Jeffrey Swanson et al., Justice Disparities: Does The ADA Enforcement System Treat People With Psychiatric Disabilities Fairly?, 66 MD. L. REv. 94, 123 (2006) (comparing the success rate of ADA claims between people diagnosed with psychiatric disorders and those with other impairments). 
ity. ${ }^{19}$ The ADA is a civil rights law that treats disability in a way similar to the Civil Rights Acts of 1964 and 1968 with regard to race, religion, gender, and ethnicity. Operationally, however, the ADA works differently than the Civil Rights Act. People seeking ADA protection must first prove they are disabled in order to be afforded protection under the Act. ${ }^{20}$

The ADA provides that "no covered entity shall discriminate against a qualified individual on the basis of disability." 21 An employer discriminates on the basis of disability if it does not make reasonable accommodations for an employee's disability, unless the employer can show the accommodations represent an undue hardship. ${ }^{22}$ The ADA defines disability as:

(A) a physical or mental impairment that substantially limits one or more major life activities of such individual;

(B) a record of such an impairment; or

(C) being regarded as having such an impairment. ${ }^{23}$

When the ADA first passed in 1990, advocates believed the language of the Act and the legislative history would provide courts with enough guidance to carry out the Act's purpose. ${ }^{24}$ However, over time, courts interpreted the Act so narrowly that its purpose seemed to get lost along the way. ${ }^{25}$ Many courts interpreted the statutory definition of disability very differently than the original advocates and drafters of the ADA envisioned. Courts considered the language of the statute clear and rarely looked to legislative intent for guidance, which gave the courts room to interpret their own definitions of terms in the Act. $^{26}$ This reading resulted in decisions excluding individuals with diabetes,

19 Chai R. Feldblum, Kevin Berry \& Emily A. Benfer, The ADA Amendments Act of 2008, 13 Tex. J. C.L. \& C.R. 187, 187 (2008).

2042 U.S.C. $\$ 12102$ (2006). See also Chai R. Feldblum, Definition of Disability Under Federal Anti-Discrimination Law: What Happened? Why? And What Can We Do About It?, 21 Berkeley J. EMp. \& LAB. L. 91, 94 (2000). Those seeking the protection of the Act must establish their own eligibility; any effort to diminish the severity of their conditions-likely done in order to keep a job-might eliminate them from the protected class. See, e.g., Evans v. Magna Group, No. 98-3125, 1999 WL 402401, at *2 (7th Cir. June 11, 1999) ("Evans has failed to present any evidence that her OCD substantially limits any of her major life activities. To the contrary, at her deposition she described her OCD as a 'fairly harmless disorder' and stated that 'her condition did not in anyway prevent her from performing her job' ...."). See generally Christopher G. Bell, The Americans with Disabilities Act, Mental Disability, and Work, in Mental Disorder, Work Disability, and the Law 203, 205 (Richard J. Bonnie \& John Monahan eds., 1997) (explaining that the ADA is largely self-administering and enforcement depends largely on the employers' conscience to make fair employment decisions). If such decisions are unfair, an employee with a psychiatric disability will be at a disadvantage. Id. See also supra note 11, citing the most recent changes to the definition of "who is disabled?"

2142 U.S.C. $\S 12112(\mathrm{a})(2006)$.

22 Id. $\S 12112(\mathrm{~b})(5)(\mathrm{A})$.

23 Id. $\$ 12102(1)$.

24 Feldblum, Berry \& Benfer, supra note 19, at 187-88.

25 Feldblum, supra note 20, at 93.

26 For example, "the term 'qualified individual' means an individual who, with or without reasonable accommodation, can perform the essential functions of the employment position that such individual holds or desires." 42 U.S.C. $\$ 12111(8)$. See generally Sharona Hoffman, Corrective Justice and Title I of the ADA, 52 Am. U. L. Rev. 1213, 1215 (2003) (arguing that the five percent win rate of ADA plaintiffs is attributable to the ADA's flawed definition of disability); Kathryn Moss et al., Unfunded Mandate: An Empirical Study of the 
epilepsy, cancer, and muscular dystrophy from coverage under the ADA. ${ }^{27}$ Although distinct from mental illness, the exclusion of these illnesses from the definition of disability under the ADA made it extremely difficult for people who were diagnosed with mental impairments to seek protection under the ADA. Such categorical exclusions, rather than case-by-case analyses of whether claimants thus diagnosed were actually disabled by their conditions, seemed to flout the ADA's original purpose.

Such applications of blanket disqualifications frustrate the intent of Congress. For example, in Sutton v. United Airlines, Inc. ${ }^{28}$ the Supreme Court read the literal text of the ADA to require "a person be presently-not potentially or hypothetically - substantially limited in order to demonstrate a disability." 29 The Sutton plaintiffs were twin sister pilots who wore corrective lenses to remedy nearsightedness. ${ }^{30}$ The lenses corrected their vision nearly one hundred percent. ${ }^{31}$ Even so, as eyeglasses-wearers, the court held that the plaintiffs' employer was permitted to disqualify them from working as pilots because of their visual impairments. ${ }^{32}$

The Supreme Court's discussions of mitigating measures to correct a disability in Sutton must be read in factual context. The Court ruled that the nearsighted pilots were not "disabled" under the ADA because their vision was presently corrected with eyeglasses, and thus they were not entitled to statutory protection. ${ }^{33}$ Sutton was a bad case for the Court to determine whether disabilities correctable with mitigating measures receive protection under the ADA. Near-sightedness is easily, and often, completely and permanently remediable. Bipolar disorder, on the other hand, may not be. Moreover, eyeglasses do not have the damaging negative effects many psychotropic drugs cause. One could speculate that a rational person may be unlikely to eschew spectacles to correct poor vision and prescription drugs that lower blood pressure because such measures typically cause few side effects (and are among the best sellers in the pharmaceuticals industry). With such disorders, the disease itself does not interfere with use of the corrective measure. That is often not true in cases of mental illness. A truly afflicted individual may experience persistent psychiatric symptoms that "prevent the person from having insight into the need for medication." ${ }^{34}$ Nearly all psychotropic drugs have physical or mental sequel-

Implementation of the Americans with Disabilities Act by the Equal Employment Opportunity Commission, 50 U. Kan. L. Rev. 1 (2001).

27 See McClure v. Gen. Motors Corp., No, 03-10126, 2003 WL 21766539, at*1 (5th Cir. June 30, 2003) (plaintiff with muscular dystrophy not considered disabled); Orr v. Wal-Mart Stores, Inc., 297 F.3d 720, 722 (8th Cir. 2002) (plaintiff with diabetes not considered disabled); Chenoweth v. Hillsborough County, 250 F.3d 1328, 1329 (11th Cir. 2001); Pimental v. Dartmouth-Hitchcock Clinic, 236 F. Supp. 2d 177, 188 (D.N.H. 2002) (plaintiff with cancer not considered disabled); Todd v. Acad. Corp., 57 F. Supp. 2d 448, 454 (S.D. Tex. 1999) (plaintiff with epilepsy not considered disabled).

28 Sutton v. United Air Lines, Inc., 527 U.S. 471 (1999).

29 Id. at 482 .

30 Id. at 475 .

${ }^{31} I d$.

32 Id. at 476.

33 Id. at 482, 493-94.

34 Peter Weiden, How to Help Someone Who Stops Taking Their Medicines, http:// www.schizophrenia.com/family/compliance1.html (last visited Aug. 11, 2009). 
lae; such "persistent negative symptoms ... interfere with motivation or energy to follow through with medication." 35 The Sutton Court agreed, holding "negative side effects ... of mitigating measures" 36 are relevant in deciding whether an affirmative duty to mitigate is a condition precedent to being disabled.

A few years later in Toyota Motor Manufacturing, Kentucky, Inc. v. Williams,${ }^{37}$ the Supreme Court substantially limited what it considered to be an impairment that affects a major life activity. The Court determined an impairment is "substantially limiting" if it "prevents" or "severely restricts" an individual from performing a "major life activity." 38 It defined a major life activity as one that is of "central importance to daily life." ${ }^{39}$ Further, the Court held that this requirement must be "interpreted strictly to create a demanding standard for qualifying as disabled." 40 This language clearly evidenced the Court's intent to limit the number of people who could qualify as disabled under the ADA.

After Sutton and Toyota, the protections offered by the ADA became much more tenuous and very few people qualified for protection under the Act. As a result, Congress recently stepped in and enacted the ADAAA to attain the original intent of the $\mathrm{ADA} .{ }^{41}$

\section{B. The ADA's Application to Mental Illness}

Pre-dating the 2008 Amendments, courts rarely found mental conditions sufficiently severe so as to qualify as a disability; symptoms had to be persistent. ${ }^{42}$ Plaintiffs could not qualify for accommodations if they "caused" their disabilities, and were usually held responsible for being drug and treatment compliant. ${ }^{43}$ As set forth in Sutton, if ameliorative measures managed an indi-

35 Id. But see Joyce A. Cramer \& Robert Rosenheck, Compliance With Medication Regimens for Mental and Physical Disorders, 49 Psychiatric SERvices 196 (1998), available at http://www.psychservices.psychiatryonline.org/cgi/content/full/49/2/196 (finding fifty-eight percent of studied psychiatric patients took their medications versus seventy-six percent compliance rate for people with physical disorders).

36 Sutton, 527 U.S. at 484.

37 Toyota Motor Mfg., Ky., Inc. v. Williams, 534 U.S.184, 193-94 (2002).

38 Id. at 198.

39 Id. at 197.

$40 I d$.

41 H.R. ReP. No. 110-730, pt. 2, at 2 (2008).

42 See, e.g., Rohan v. Networks Presentations LLC, 375 F.3d 266 (4th Cir. 2004) (finding no disability status for an actress and singer with posttraumatic stress disorder ("PTSD") and severe depression stemming from childhood incest and sexual abuse). The case explains that the plaintiff "experience[d] significant mental distress when she observe[d] a parent scolding a child, or when she [saw] or interact[ed] with a man who resembles or reminds her of the likeness or mannerisms of her father, or sees such a man in a movie." Id. at 269. Interactions of this nature caused the plaintiff "flashbacks or abreactions to when she was abused as a child." Id. When the plaintiff "relive[d] the molestation, she experience[d] a variety of physiological reactions, including (at different times) hyperventilation, inability to speak, inability to open her eyes, gagging, bodily pain, and/or staring off into space." Id. The court found that "[i]ntermittent manifestations of an illness are insufficient to establish a substantial limitation on a major life activity." Id. at 276.

43 See, e.g., Spades v. City of Walnut Ridge, 186 F.3d 897, 900 (8th Cir. 1999) ("The record shows that Spades took medication and received counseling for his alleged disability of depression. He concedes that resort to medicines and counseling 'allow him to function 
vidual's disability, then the ADA offered them no protection, with courts often blindly accepting a doctor's treatment suggestions. ${ }^{44}$ Courts often read the Act's provision requiring a disability to "substantially limit" a major life activity as essentially disqualifying any person who is able to maintain a job from no protection under the ADA, no matter how difficult it may be for the individual to hold the job. ${ }^{45}$ If a plaintiff complained that his employer "regarded" him as disabled, and therefore treated him adversely, he had no claim for accommodation unless he could also prove that he was, indeed, substantially limited. ${ }^{46}$

These perverted results may have resulted from poor drafting, judicial obduracy, or prejudice. As the First Circuit opined in an analogous Federal Rehabilitation $\mathrm{Act}^{47}$ case:

A plaintiff . . . confronts a potential 'Catch 22 ' . . . She must show both that her impairment substantially limits a major life activity and that she is 'otherwise qualified' for her job, ... In shorthand, the law requires the individual to be both substantially limited and reasonably functional. ${ }^{48}$

A plethora of lawsuits and an avalanche of scholarly articles have failed to create an unwavering taxonomy of activities that constitute "major life activities." Some litigation has focused on whether working is a major life activity. ${ }^{49}$ The Equal Employment Opportunity Commission ("EEOC")

without limitation.' Thus, his depression is corrected and cannot substantially limit a major life activity - a requirement for finding that an individual is disabled within the meaning of the ADA.”); Keoughan v. Delta Airlines, Inc., No. 96-4072, 1997 U.S. App. LEXIS 12232, at *3-6 (10th Cir. May 27, 1997) (The plaintiff, Ms. Keoughan, diagnosed with bipolar disorder, had stopped taking her medication (lithium) for the disorder, and "the district court determined that it was undisputed that Ms. Keoughan's disorder could be controlled and stabilized with lithium, and therefore she could perform all the essential functions of her job. Because the facts also show that Ms. Keoughan failed to take her lithium, the court granted Delta's motion for summary judgment."); Siefken v. Vill. of Arlington Heights, 65 F.3d 664, 665-67 (7th Cir. 1995) (A probationary police officer experienced a diabetic reaction while on duty in his squad car which resulted in disorientation and memory loss, allegedly due to his failure to monitor his insulin. "[W]hen an employee knows that he is afflicted with a disability, needs no accommodation from his employer, and fails to meet 'the employer's legitimate job expectations,' . . . due to his failure to control a controllable disability, he cannot state a cause of action under the ADA." (citing DeLuca v. Winer Indus., Inc., 53 F.3d 793, 797 (7th Cir. 1995)); Johnson v. Maynard, No. 01 Civ. 7393 (AKH), 2003 U.S. Dist. LEXIS 2676, at*12 (S.D.N.Y. Feb. 25, 2003) (Plaintiff's doctors reported "she had not been complying with her outpatient treatment. [Her] failure to take advantage of mitigating measures does not make her a qualified individual under the ADA."); Bowers v. Multimedia Cablevision, Inc., No. 96-1298-JTM, 1998 U.S. Dist. LEXIS 19319, at*11 (D. Kan. Nov. 3, 1998) ("In this case, it is undisputed that plaintiff's condition does not substantially limit him in his major life activities when he takes his medication as prescribed. In fact, his one panic attack occurred after he had quit taking his medication without so informing his doctor. The plaintiff cannot gain ADA protection by unilaterally deciding, without justification, not to use prescribed medication which corrects or alleviates his condition.").

44 Sutton v. United Air Lines, Inc., 527 U.S. 471, 482 (1999).

45 See, e.g., Johnson v. City of N.Y., 326 F. Supp. 2d 364, 368-69 (E.D.N.Y. 2004); Evans

v. Magna Group, No. 98-3125, 1999 WL 402401, at *2 (7th Cir. June 11, 1999).

46 Johnson, 326 F. Supp. 2d at 369.

47 Rehabilitation Act of 1973, 29 U.S.C. $§ 791$ (2006).

48 Calero-Cerezo v. U.S. Dep't of Justice, 355 F.3d 6, 22 (1st Cir. 2004).

49 See, e.g., Hoard v. CHU2A, Inc. Architecture Eng'g Planning, No. 06-15447, 2007 U.S. App. LEXIS 15317, at*6 (11th Cir. June 27, 2007) (holding that plaintiff failed to establish that his employer treated him as though his illness substantially limited his ability to work). 
Regulations define major life activities as "functions such as caring for oneself, performing manual tasks, walking, seeing, hearing, speaking, breathing, learning, and working." 50 The "Interpretive Guidance" to the EEOC Regulations further note "other major life activities include, but are not limited to, sitting, standing, lifting, [and] reaching." 51 The EEOC has also identified "[m]ental and emotional processes such as thinking, concentrating, and interacting with others" as other examples of major life activities. ${ }^{52}$

The Ninth Circuit adopted such a broad view of the term "major life activity" in denying an employer's motion for summary judgment in McAlindin $v$. County of San Diego. ${ }^{53}$ In that case, the plaintiff, a systems analyst, argued that his employer violated the ADA when it failed to transfer him to a less stressful job. ${ }^{54}$ The court held:

These evaluations suggest that McAlindin suffers from a total inability to communicate at times, in addition to a more subtle impairment in engaging in meaningful discussion. His alleged "fear reaction" and "communicative paralysis" are sufficiently severe to raise a genuine issue of material fact about his ability to interact with others. 55

The dissenting judge, however, articulated a common concern about the mentally ill:

[N]ot only do we serendipitously create a mischievous Pandora's box, but we then open it with a flourish and invite into federal court all but the 'cantankerous' to sue those employers with whom they cannot get along. Employers beware, now you may have an obligation at the risk of being sued to accommodate someone who does not possess the ability to "get along with others." Not only is this "disability" vague, but it's bizarre, ominous, and wholly outside of the group of serious disabilities Congress intended to cover with this statute. Does this opinion suggest that a person's foul temperament may no longer be a reason to deny that person a job? ${ }^{56}$

5029 C.F.R. $\$ 1630.2(\mathrm{i})$ (2008). The EEOC regulations define "major life activities" broadly.

5129 C.F.R. app. $§ 1630$ (2008) (providing interpretive guidance on Title I of the Americans with Disabilities Act).

52 U.S. Equal Employment Opportunity Comm'n, Compliance Manual § 902.3(b), http://www.eeoc.gov/policy/compliance.html. Agency guidelines and interpretations do not have the force and effect of law; however, they do offer the court guidance. See, e.g., Meritor Sav. Bank v. Vinson, 477 U.S. 57, 65 (1986) (The court frequently looks to EEOC guidelines for guidance in discrimination cases, which, " while not controlling upon the courts by reason of their authority, do constitute a body of experience and informed judgment to which courts and litigants may properly resort for guidance'" (citation omitted)); see also Toyota Motor Mfg., Ky., Inc. v. Williams, 534 U.S. 184, 194 (2002) (“[W]e have no occasion to decide what level of deference, if any, [applicable EEOC regulations] are due."). 53 McAlindin v. County of San Diego, 192 F.3d 1226, 1235-36 (9th Cir. 1999).

54 Id. at 1230-31 ("McAlindin received a 'provisional promotion' in early 1989, which brought new, very stressful duties. In June 1989, McAlindin complained about a vendor's misconduct, yet his supervisors disregarded his complaints. According to McAlindin's supervisor, McAlindin became agitated and started shouting in an accusatory manner during the meeting. Soon thereafter, McAlindin sought and was granted leave due to "work stress." ").

55 Id. at $1235-36$.

56 Id. at 1240 (Trott, J., concurring in part and dissenting in part). See also Evans v. Consumer Info. \& Dispute Resolution, No. 05 Civ. 8252 (AJP), 2006 U.S. Dist. LEXIS 26182, at *38-51 (S.D.N.Y May 5, 2006). 
The majority of Federal Circuit Courts of Appeals have agreed with the dissent. ${ }^{57}$ As the First Circuit has explained,

[t]he concept of "ability to get along with others" is remarkably elastic, perhaps so much so as to make it unworkable as a definition. While such an ability [i.e., getting along with others] is a skill to be prized, it is different in kind from breathing or walking, two exemplars which are used in the regulations. Further, whether a person has such an ability may be a matter of subjective judgment; and the ability may or may not exist depending on context. . . To impose legally enforceable duties on an employer based on such an amorphous concept would be problematic. ${ }^{58}$

Case law illustrates just how intractable notions of mental illness may be. For example, in Krocka v. City of Chicago, ${ }^{59}$ the Seventh Circuit sanctioned what, for all intents and purposes, looks like the discriminatory treatment of a police officer. ${ }^{60}$ The court explained that an ADA violation did not occur where the police department forced an officer to participate in a mandatory supervision program, typically reserved for officers facing disciplinary action, after the officer revealed he was taking an antidepressant. ${ }^{61}$ The officer argued that "his depression substantially limit[ed] his ability to perform the major life activity of working," and in the alternative, alleged an ADA violation because the Department "regarded" him as disabled by requiring him to participate in an employee assistance program usually reserved for officers with disciplinary problems. ${ }^{62}$ Treating a worker as if he were disabled provides an alternate basis for protection under the ADA. ${ }^{63}$ The Seventh Circuit draws a distinction between limitations and disabilities, and has held: "Employers do not run afoul

57 See McAlindin, 192 F.3d at 1234; see also Davis v. Univ. of N.C., 263 F.3d 95, 101 n.4 (4th Cir. 2001) (finding plaintiff with dissociative disorder could not claim that the ability to get along with others is a major life activity). Most of the cases on this issue can be found in Jennifer N. Randolph, Note, Problem Employees: “Merely Cantankerous" or Substantially Limited in Their Ability to Interact with Others?, 74 U. CIN. L. REv. 1135 (2006).

58 Soileau v. Guilford of Me., Inc., 105 F.3d 12, 15 (1st Cir. 1997). Other courts have held similarly, when a plaintiff requested accommodation for a psychiatric condition that required time off from work. See, e.g., Criado v. IBM Corp., 145 F.3d 437, 443 (1st Cir. 1998).

59 Krocka v. City of Chi., 203 F.3d 507 (7th Cir. 2000).

$60 \mathrm{Id}$. at 510 .

61 Id. at 511 .

62 Id. at 511, 513-14. The court concluded that the district court did not error in holding that Krocka was not substantially limited in a major life activity of working. Id. at 513. The court also concluded that Krocka did not provide sufficient evidence to establish his employer "regarded" him as disabled. Id. at 514. Therefore the court held the ADA did not protect Krocka. Id. at 514-15.

63 Sutton v. United Air Lines, Inc., 527 U.S. 471, 475-76, 489 (1999). In Sutton, two sibling pilots lost their bid for ADA protection due to severe myopia which disqualified them from flying airplanes. Id. at 475-76. The Supreme Court noted that in order to make out a claim under the 'regarded as' prong, "it is necessary that a covered entity entertain misperceptions about the individual." Id. at 489. These misperceptions may take the form of believing "either that one has a substantially limiting impairment that one does not have or that one has a substantially limiting impairment, when, in fact, the impairment is not so limiting." Id. Reading Sutton's statement of the 'two apparent ways' as exhaustive, the Krocka court concluded that the police officer was neither perceived of as being disabled, nor was he disabled. Krocka, 203 F.3d at 513-14. The City did not consider Krocka disabled; in fact they expected him to work. Id. at 514. Officers who have run afoul of department practices, like those who suffer from depression, might need a bit more help and supervision. Id. at 514-15. 
of the ADA when they make employment decisions based on physical or mental characteristics that are not impairments or that are 'limiting, but not substantially limiting' such that they do not rise to the level of a disability under the ADA definition." 64

Krocka deserves close examination because it gives a legal imprimatur to irrational and discriminatory treatment by an employer. ${ }^{65}$ In the early 1980 s, Vincent Krocka joined the Chicago Police Department as a police officer. ${ }^{66} \mathrm{He}$ received a decade of good performance evaluations. ${ }^{67}$ In 1990, Krocka began receiving medical treatment for severe depression, including taking Prozac to alleviate his condition. ${ }^{68}$ As a result of the medication, his psychological condition improved. ${ }^{69}$ He continued to receive good performance evaluations. ${ }^{70}$

Ignoring Krocka's two years of successful performance while taking Prozac, in 1992, the Department learned that Krocka was taking the medication and placed him on medical leave pending the outcome of physical and psychological evaluations to determine his fitness for continued duty as a police officer. $^{71}$ After the evaluating physicians concluded that Krocka was fit for duty, he was allowed to return to work, subject to the condition that he participate in the Department's Personnel Concerns Program ("PCP"). ${ }^{72}$ Under that program, the Department closely monitors participants to ensure no problems occur. $^{73}$ Department employees check in with such monitored officers throughout each shift and often accompany them on radio calls. ${ }^{74}$ The Department puts all officers taking prescription psychotropic medication in the PCP because they are deemed to have "significant deviations from an officer's normal behavior." " 5 Labeling a well-performing police officer on a psychotropic medication 'deviant' demonstrates stereotypical thinking. However, the ADA only protects the narrow class of employees who are, or are perceived to be, disabled. Simply thinking of those employees as deviant, or dangerous, will not bring them within the aegis of the ADA.

Judges, as well as employers, may hold beliefs that contradict the spirit of the ADA. A Texas federal district court judge rejected the notion that getting along with others qualifies as a "major life activity" in granting an employer's motion for summary judgment in Logan v. Nicholson. ${ }^{76}$ After a history of

64 Krocka, 203 F.3d at 514.

65 Id. at 511.

66 Id. at $510-11$.

67 Id. at 511 .

68 Id.

69 Id.

$70 I d$.

71 Id.

72 Id.

73 Id.

74 Id.

75 Id.

76 Logan v. Nicholson, No. H-04-4178, 2006 U.S. Dist. LEXIS 34359, at *21-22 (S.D. Tex. May 30, 2006). This case was brought under the Rehabilitation Act, a predecessor to the ADA with essentially identical proscriptions, but applicable only to federal employers. The Rehabilitation Act prohibits discrimination by a federal employer against qualified individuals with disabilities. 29 U.S.C. § 794(a) (2006). The Rehabilitation Act provides, in part, "[n]o otherwise qualified individual with a disability ... shall, solely by reason of her or his 
productive employment, the employer began to require the plaintiff to attend staff meetings, which she characterized as too stressful. ${ }^{77}$ The plaintiff was excused from the meetings for a short while and was allowed to simply read the notes from the meetings. ${ }^{78}$ The employer eventually refused to continue this accommodation because "her attendance at the team meetings was an important part of her job duties." 79 The court agreed. In so finding, the court failed to address the implicit issue: the woman had a serious illness, for which she faithfully sought treatment, which prevented her from working. That, and only that, disabled her. Despite that fact, the court reasoned:

Plaintiff's mental impairment caused her to experience stress in staff meetings which were characterized by disagreements and raised voices. Plaintiff does not argue, and cannot argue given the facts in the record, that she is substantially limited in her ability to interact or communicate with others on a very basic level.

The court cannot subscribe to the view that Plaintiff's professed mood swings and stress-related symptoms experienced in contentious staff meetings are significant limitations to any major life activity ... ${ }^{80}$

Accordingly, the court held that an accommodation was not legally required despite the plaintiff's inability to keep working for her current employer. ${ }^{81}$

In Bell v. Gonzalez, ${ }^{82}$ a district court granted an employer's motion to dismiss an ADA claim by a federal worker with Tourette's Syndrome, finding that his illness did not significantly impair him. ${ }^{83}$ Tourette's Syndrome is a neurological disorder that manifests itself at an early pre-teen age and it is characterized by verbal and motor tics. ${ }^{84}$ Co-workers or employers are likely

disability, be excluded from the participation in, be denied the benefits of, or be subjected to discrimination under any program or activity . . . conducted by any Executive agency ...." Id. In order to state a claim for relief under the Rehabilitation Act, a plaintiff must prove that he or she: (1) was an "individual with handicaps"; (2) was "otherwise qualified"; (3) worked for a "program or activity" receiving federal financial assistance; and (4) was "adversely treated solely because of his handicap." Chandler v. City of Dallas, 2 F.3d 1385, 1390 (5th Cir. 1993). The Rehabilitation Act incorporates the standards used in ADA cases, which are subject to the Title VII burden-shifting analysis. Daigle v. Liberty Life Ins. Co., 70 F.3d 394, 396 (5th Cir. 1995). See also Daugherty v. City of El Paso, 56 F.3d 695, 69798 (5th Cir. 1995).

77 Logan, 2006 U.S. Dist. LEXIS 34359, at *3.

78 Id. at $* 4$.

79 Id. at $* 3$.

80 Id. at $* 22$ (major life activity as recognized by the Federal Rehabilitation Act). See supra note 41 .

81 Logan, 2006 U.S. Dist. LEXIS 34359, at *22-23.

82 Bell v. Gonzalez, 398 F. Supp. 2d 100 (D.D.C. 2005).

83 Id. at 101-02. The court must focus on whether the plaintiff, "through the exercise of his own skills, is capable of communicating with others, in contrast to examining whether others wish to avoid interacting with him because of his impairment." Id. at 101. Essentially this means that if he can talk, even if no one will listen, he is not disabled-even if he cannot work. See Criado v. IBM Corp., 145 F.3d 437, 443 (1st Cir. 1998) ("Criado's physician testified that if given a significant leave she could adjust to her situation and after he experimented with medication she might return to her previous level of functionality. This evidence indicates that with a reasonable accommodation Criado could perform the essential functions of her job.").

84 Nat'l Tourette Syndrome Ass'n, What is Tourette Syndrome?, http://www.tsa-usa.org/ Medical/whatists.html (last visited Aug. 11, 2009). 
\begin{tabular}{lllll}
\hline |lserver05\productnlNINVJ\9-3\NVJ304.txt & unknown & Seq: 13 & 1-OCT-09 & 9:28 \\
\hline
\end{tabular}

to feel strong reactions to a person with Tourette's Syndrome. ${ }^{85}$ However, Tourette's is very rarely physically disabling, and "[m]ost people with [Tourette's Syndrome] . . . will lead productive lives." 86 Experts blame "social attitudes" and ignorance for lost opportunities those with the illness suffer. ${ }^{87}$ Many employers could accommodate an individual with Tourette's Syndrome by reassignment, providing "tic" breaks, and educating the workforce about the illness. ${ }^{88}$ The Bell court seemed to appreciate the unfairness and potential discrimination, but it nonetheless ruled against the plaintiff. ${ }^{89}$

Measuring whether a plaintiff is 'substantially limited' in interacting with others through the reactions of society would result in defining a disability based on the subjective and varied range of reactions of the persons with whom a plaintiff happens to come into contact, and would focus the inquiry away from a plaintiff's own abilities. $^{90}$

These lower court decisions followed the lead of the United States Supreme Court, further narrowing the ADA's protections in a manner contrary to its legislative purpose. ${ }^{91}$

\section{Overview of the ADAAA}

The ADAAA attempts to expand protections for the disabled by broadening the scope of persons considered to be disabled and clarifying the original intent of the ADA.92 Eighteen years after the passage of the ADA, "many individuals with physical and mental impairments whom Congress intended to protect are not covered under the law, due to a series of Supreme Court decisions interpreting the definition of disability." 93 The House Report accompanying the ADAAA demonstrates: "The purpose of the bill is to restore protection for the broad range of individuals with disabilities as originally envisioned by Congress by responding to the Supreme Court's narrow interpretation of the definition of disability." 94 The language of the ADA itself instructed courts and the EEOC to read the Act broadly. ${ }^{95}$

Congress specifically addressed and amended several parts of the ADA, four of which are crucial for employees with psychiatric illnesses. ${ }^{96}$ The ADAAA redefines a "disability" as an impairment that is episodic or in remission, if the impairment substantially limits a major life activity when active. ${ }^{97}$

85 Mitzi Waltz, Nat'l Tourette Syndrome Ass'n, Employment: Getting a Job and Keeping It, http://www.tsa-usa.org/People/LivingWithTS/Employment.htm (last visited Aug. 11, 2009).

86 Nat'l Tourette Syndrome Ass'n, supra note 84.

87 Waltz, supra note 85.

88 Id.

89 Bell v. Gonzalez, 398 F. Supp. 2d 100, 102 (D.D.C. 2005).

90 Id. at 101.

91 H.R. ReP. No. 110-730, pt. 2, at 5-6 (2008).

92 ADA Amendments Act of 2008, Pub. L. No. 110-325, § 2, 122 Stat. 3553, 3553 (amending the Americans with Disabilities Act of 1990).

93 H.R. ReP. No. 110-730, pt. 1, at 7 (2008).

94 H.R. ReP. No. 110-730, pt. 2, at 5.

95 ADA Amendments Act of $2008 \S 2$.

96 Id.

97 Id. $\S 4$ (explaining amendments to section three of the American with Disabilities Act of 1990, 42 U.S.C. $§ 12102$ (2006)). 
Under the ADAAA, Congress liberalized the meaning of "substantially limits" $" 98$ and broadened the list of "major life activities." "99 It instructs that disabilities can include impairments that are episodic or controlled by drugs, therapy or learned behavioral, or adaptive neurological modifications. ${ }^{100}$ The Act also explicitly reverses Sutton by directing courts not to consider mitigating measures when determining whether an impairment substantially limits a major life activity. ${ }^{101}$ However, Congress made an exception in allowing for the consideration of the mitigating measures of corrective lenses and eyeglasses. ${ }^{102}$

The ADAAA also allows a plaintiff to be "regarded as" disabled if she is treated adversely in the workplace because of her employer's belief that she has a mental disability, even if she does not. ${ }^{103}$ Further, in the Act's "Findings and Purposes," Congress states that judicial and agency interpretations have eliminated "protection for many individuals Congress intended to protect," that courts read "the term 'substantially limits' to require a greater degree of limitation" than the original ADA intended, and thus the Act redefines the term to mean "materially restricts." 104 The House Report accompanying the Act stated that:

The Committee intends to lessen the standard of establishing whether an individual has a disability for purposes of coverage under the ADA, and to refocus the question on whether discrimination on the basis of disability occurred. . .

....

Too often cases have turned solely on the question of whether the plaintiff is an individual with a disability; too rarely have courts considered the merits of the discrimination claim, such as whether adverse decisions were impermissibly made by the employer on the basis of disability, reasonable accommodations were denied inappropriately, or qualification standards were unlawfully discriminatory. ${ }^{105}$

Congress further clarified that it did not intend for the threshold question of disability to be used as a means of excluding individuals from coverage. ${ }^{106}$ Finally, Congress expanded the statutory language to clarify that "major life activities" include many symptoms of mental illness: "sleeping . . speaking, breathing, learning, reading, concentrating, thinking, communicating and working." 107

$98 I d . \S 3$.

$99 \mathrm{Id}$.

100 Id. $\$ 4$.

101 Id. $\S \S 2,4$ (explaining amendments to section three of the American with Disabilities Act of 1990, 42 U.S.C. $\$ 12102$ (2006)).

102 Id. Nevertheless, the Act provides "a covered entity shall not use qualification standards, employment tests, or other selection criteria based on an individual's uncorrected vision unless the standard, test, or other selection criteria, as used by the covered entity, is shown to be job-related for the position in question and consistent with business necessity." Id. $\S 5$.

103 Id. $\S 4$ (explaining amendments to section three of the American with Disabilities Act of 1990, 42 U.S.C. $\$ 12102$ (2006)).

104 Id. § 3(2). See also H.R. REP. No. 110-730, pt. 1, at 2 (2008) ("The term 'substantially limits' means materially restricts").

105 H.R. ReP. No. 110-730, pt. 1, at 7-8.

106 Id. at $16-17$.

107 Id. at 27. 
The ADAAA dramatically expands the definition of disability, providing protection for many more people than previously available under the ADA. Although the Act brings society one step closer to protecting the mentally and physically disabled from discrimination, more steps are required to completely eliminate the discriminatory effects the disabled suffer throughout their lives.

\section{The ADAAA Does Not Prohibit Employers From Requiring Non- Medical Tests as a Means of Identifying Certain Traits Affecting Work-Related Criteria}

Despite its benefits, the ADAAA does not appear to include legislation prohibiting employers from requiring employees (or potential employees) to take non-medical tests identifying certain traits that could affect work-related criteria. Considering that legislation is silent on this issue, courts may assume Congress had no intention to amend the EEOC's "testing" exception to the ADA. The ADA prohibited an employer from asking questions of an applicant seeking to discover disabilities. ${ }^{108}$ Nor could the employer require medical examinations of an applicant until after an offer of employment had been made to the applicant. ${ }^{109}$ However, the EEOC provided an exception: "[T]ests used to identify such traits as poor judgment, chronic lateness, impulse control . . . are not medical tests." 110

In answer to a written inquiry asking whether an employer could use a handwriting sample or psychological test to screen for "personality traits/characteristics such as a tendency towards a quick temper, inability to concentrate on projects, [or] slow v. quick thinking processes," 111 the EEOC provided an equivocal answer:

$[\mathrm{P}]$ sychological tests are medical if they provide evidence that would lead to identifying a mental disorder or impairment, such as those listed in the Diagnostic and Statistical Manual of Mental Disorders (DSM-IV). For example, a test designed to reveal whether a characteristic such as 'slow' thinking or 'inability to concentrate' is the result of a mental or psychological impairment is a medical examination. By contrast, tests that are designed and used to measure traits or characteristics such as honesty, tastes, and habits are not 'medical.'112

In Karraker v. Rent-A-Center, Inc. ${ }^{113}$ the Seventh Circuit decided using the Minnesota Multiphasic Personality Inventory (MMPI) as an employment screen constituted discrimination under the ADA. ${ }^{114}$ The court reiterated the

10842 U.S.C. $\S 12112(\mathrm{~d})(2006)$.

109 Id. $\S 12112(\mathrm{~d})(1)-(2)$.

110 Letter from Joyce Walker-Jones, Acting Assistant Legal Cousel, ADA Policy Division, U.S. Equal Employment Opportunity Comm'n, to member of the public (July 1, 2003) (available at http://www.eeoc.gov/foia/letters/2003/ada_pre-offer_exams.html). See U.S. Equal Employment Opportunity Comm'n, Notice 915.002: Enforcement Guidance on the Americans with Disabilities Act and Psychiatric Disabilities (1997), available at http://www.eeoc.gov/policy/docs/psych.html.

111 Letter from Joyce Walker-Jones, supra note 110.

112 Id.

113 Karraker v. Rent-A-Center, Inc., 411 F.3d 831 (7th Cir. 2005).

114 Id. at 837; Karraker v. Rent-A-Center, Inc., 492 F.3d 896, 897 (7th Cir. 2007) (awarding attorneys' fees to plaintiff when, after remand, the district court ordered the company-wide destruction of all MMPI test results); Karraker v. Rent-A-Center, Inc., 431 F. Supp. 2d 883 
salutary purposes of the ADA to be "the elimination of discrimination against individuals with disabilities." 115 The court also recognized Congress' attempt to remedy "attitudinal barriers resulting from unfounded stereotypes and prejudice."116 Despite such mellifluous proclamations, another case, Ward v. Merck \& Co.,${ }^{117}$ involving a chemist fired for refusing to submit to a fitnessfor-duty mental health examination by company doctors did not amount to a violation. ${ }^{118}$ In that case, the court did not find impermissible discrimination because the employee's odd behavior created a legitimate business reason for the exam; ${ }^{119}$ his co-worker described him as "walking around like he's a zombie." 120

Although the ADA prohibited tests that "screen out (or tend to screen out) people with disabilities," 121 employers can administer medical tests that are "job-related and consistent with business necessity." 22 Thus, a description of a worker as a "zombie" created a reason for discharge. ${ }^{123}$ Congress did not appear to rectify this problem in drafting the ADAAA. In essence, employers could potentially continue to use these tests to weed out the mentally disabled if they can find a legitimate business interest for requiring an employee to take a non-medical test that attempts to measure a type of behavior.

The sum total of disability jurisprudence represents a wholesale failure to accommodate mental illness. Results contradict the ADAAA's mandate that employers tolerate such unique disabilities. The disability law utilizes "a difference model," rather than a formal equality standard, under which an employer is required to the treat all employees the same, regardless of race, gender, or national origin. ${ }^{124}$ As a result, one scholar notes, "individuals seeking reasonable accommodation run into resistance from courts that view accommodations as a form of preferential treatment not unlike affirmative

(C.D. Ill. 2006). See also Jennifer Gonzales-Frisbie, Comment, Personality Tests In Jeopardy: An Evaluation of the Seventh Circuit's Decision in Karraker v. Rent-A-Center and Its Impact on the Future Use of Personality Tests in Pre-Employment Screening, 9 U. PA. J. LAB. \& EMP. L. 185, 187 (2006). The MMPI might be the "most popular personality test in the world" and used by many employers, although it was created in the 1930s to help diagnose psychiatric disorders. Id.

115 Karraker, 411 F.3d at 834 (citing 42 U.S.C. § 12112(d)(1) (2006)).

116 Id. Employees have had mixed results in challenging the use of these tests in other federal and state courts. See generally 9 Lex K. Larson, Employment Discrimination $\S 154.07$ (2d ed. 2009).

117 Ward v. Merck \& Co., 226 F. App'x 131 (3d Cir. 2007).

118 Id. at $132-33$.

119 Id. at $138-39$.

$120 \mathrm{Id}$. at 137.

121 Karraker, 411 F.3d at 834.

122 Id. at 835.

123 Ward, 226 F. App'x at 137.

124 See Pamela S. Karlan \& George Rutherglen, Disabilities, Discrimination, and Reasonable Accommodation, 46 Duke L.J. 1, 10-11 (1996) (stating the ADA "requires employers to treat some individuals ... differently than other individuals"). Cf. 42 U.S.C. \$2000e-2(a) (2006), unconstitutional as applied by Rweyemamu v. Cote, 520 F.3d 198, 209 (2d Cir. 2008), limited on constitutional grounds by Miller v. Bay View United Methodist Church, Inc. 141 F. Supp. 2d 1174, 1180 (E.D. Wis. 2001). 
action." ${ }^{25}$ The ADAAA does not prevent employers from using personality tests as proxies for discrimination. Perhaps, the EEOC will address this issue when it provides guidelines for the ADAAA, but as of yet, individuals with mental disabilities or illnesses remain vulnerable to discrimination in employment.

\section{Paul Wellstone and Pete Domenici Mental Health Parity and AdDiction EQuity Act}

\section{A. Overview of the Law}

The Paul Wellstone and Pete Domenici Mental Health Parity and Addiction Equity Act ("Wellstone Act") passed as part of the Emergency Economic Stabilization Act of 2008. ${ }^{126}$ The Wellstone Act does not mandate benefits, but it states that if benefits are provided by any employer, "the financial requirements applicable to such mental health or substance use disorder benefits" and the "treatment limitations" can be "no more restrictive than the predominant financial requirements applied to substantially all medical and surgical benefits covered by the plan."127

Additionally, the Act provides that employers cannot implement "cost sharing requirements," separate treatment limitations that are applicable only with respect to mental health or substance use disorder benefits. ${ }^{128}$ The law defines " 'financial requirement' [to include] deductibles, copayments, coinsurance, and out-of-pocket expenses."129 "The term 'treatment limitation' includes limits on the frequency of treatment, number of visits, days of coverage, or other similar limits on the scope or duration of treatment."130 Although employers may choose not to offer any mental health insurance, if they cover psychiatric, emotional, or substance abuse disorders, parity rules apply.

Federal officials estimate the Wellstone Act will improve mental health coverage for at least 113 million people. ${ }^{131}$ The Congressional Budget Office estimates the Wellstone Act will only "increase premiums by an average of about two-tenths of 1 percent." 132

The Wellstone Act amends the 1996 Mental Health Parity Act ("MHPA"), ${ }^{133}$ a limited measure that simply requires group health plans to equalize lifetime and annual dollar limits for mental health and other covered

125 Cheryl L. Anderson, What is "Because of the Disability" under the Americans with Disabilities Act? Reasonable Accommodation, Causation, and the Windfall Doctrine, 27 Berkeley J. Emp. \& Lab. L. 323, 325 (2006) (citing Equal Employment Opportunity Comm'n v. Humiston-Keeling, Inc., 227 F.3d 1024, 1029 (7th Cir. 2000) (calling a reasonable accommodation claim "affirmative action with a vengeance")).

126 H.R. 1424, 110th Cong. § 512 (2008) (enacted).

127 Id. $\S 512(\mathrm{a})(1)$.

128 Id.

$129 I d$.

$130 \mathrm{Id}$.

131 Robert Pear, Equal Coverage for Mental and Physical Ailments Is Required in Bailout Law, N.Y. Times, Oct. 6, 2008, at A13.

132 Id.

133 Mental Health Parity Act of 1996, 29 U.S.C. § 1185a (2006). 
benefits. ${ }^{134}$ Neither the original nor the amended laws mandate benefits, and the laws only apply to self-insured plans covered by ERISA and exclude employers with fewer than fifty covered employees. ${ }^{135}$ Until 2010, when the Wellstone Act becomes effective, employer plans are allowed to limit mental health benefits, financial requirements can be disparate, and benefits for substance abuse and chemical dependency are explicitly exempt from parity requirements. ${ }^{136}$ Under the MHPA, plans can exclude certain categories of mental illness from coverage, and benefits for substance abuse and chemical dependency are explicitly exempt from parity requirements. ${ }^{137}$ Any business could apply for an exemption to the MHPA if it could demonstrate that compliance with the law would increase its overall group health plan costs by more than one percent. ${ }^{138}$

Unfortunately, the MHPA did not illegalize many of the tools used by health insurers to limit mental health coverage, such as higher co-payments and deductibles, and lower limits on inpatient days and outpatient visits. ${ }^{139}$ Even though one required only moderate changes in benefits for the mentally ill, Congress debated this initial measure for four years before making the MHPA law. ${ }^{140}$

Significant disparities allowed under the MHPA are those the new Wellstone Act is intended to remedy. The new law retains the small employer and economic hardship exemptions. ${ }^{141}$ Large employers enjoy enormous subsidization: the United States tax expenditure reflects what the federal government

134 Maggie D. Gold, Must Insurers Treat All Illnesses Equally?-Mental vs. Physical Illnesses: Congressional and Administrative Failure to End Limitations to and Exclusions from Coverage for Mental Illness in Employer-Provided Health Benefits Under the Mental Health Parity Act and the Americans with Disabilities Act, 4 Conn. Ins. L.J. 767, 771 (1998) ("[I]dealistic access goals bargained away and dismantled by cost-containment concerns.").

13529 U.S.C. $§ 1185$ a.

136 See generally Beth Mellen Harrison, Recent Development, Mental Health Parity, 39 Harv. J. on Legis. 255 (2002).

137 U.S. Dep't of Labor, Mental Health Benefits, http://www.dol.gov/dol/topic/health-plans/ mental.htm (last visited Aug. 12, 2009).

138 See generally U.S. Dep't of Labor, Frequently Asked Questions About the Mental Health Parity Act, http://www.dol.gov/ebsa/faqs/faq_consumer_mentalhealthparity.html (last visited Aug. 12, 2009).

139 Data showed that insurers used these limits to offset the cost of parity in lifetime and annual benefits. Robert Pear, House Approves Bill on Mental Health Parity, N.Y. Times, Mar. 6, 2008, at A14.

140 On May 12, 1992, during the 102nd Congress Senators Pete Domenici and John Danforth first introduced mental health parity legislation. Equitable Health Care for Severe Mental Illnesses Act of 1992, S. 2696, 102d Cong. (1992). "On July 18, 2007, the Committee on Education and Labor met to markup House Bill 1424, the Paul Wellstone Mental Health and Addiction Equity Act of 2007.” H.R. REP. No. 110-374, pt. 1, at 20 (2007). "The Committee adopted by voice vote an amendment in the nature of a substitute offered by Chairman Miller and reported the bill favorably as amended by a vote of 33-9 to the House of Representatives." Id.

141 H.R. 1424, 110th Cong. § 512(c)(2) (2008) (enacted). Cost exemption (i) $2 \%$ of the first year, and (ii) $1 \%$ of each subsequent years, as determined by plan actuaries. Id. 
gives up in potential tax revenue to inspire corporations to insure their workers, currently about $\$ 200$ million per year. ${ }^{142}$

The Wellstone Act brings us one step closer to having mental health diseases insured in the same manner as allopathic medicine is insured. This is important because the majority of scientific evidence clearly proves "mental illnesses represent real diseases of the brain." ${ }^{143}$ For example, "[g]enetic mutations and unlucky combinations of normal genes contribute to the risk of autism and schizophrenia," just like physical ailments caused by genetic mutations. ${ }^{144}$ As such, health care costs and coverage should not be based on an arbitrary line distinguishing between a mental healthcare and allopathic medicine. In both cases, people are sick and in need of care. In both cases, when people receive the necessary treatment, people have the potential to get better and re-enter society as productive and independent citizens.

\section{B. The Wellstone Act Still Leaves Room for Potential Disparities}

As promising as the Wellstone Act may be, obstacles remain. This section discusses why employers should recognize offering broad mental health coverage to their employees redounds to their benefit.

Because of comprises between Congress and other vested interests, including business and insurance leaders, ${ }^{145}$ an employer may choose not to cover certain mental health treatments under the Wellstone Act. ${ }^{146}$ Opponents were less hostile towards the Act after the House members agreed not to require mental health plans to cover all conditions specified in the Diagnostic and Statistical Manual of Mental Disorders IV ("DSM"), ${ }^{147}$ a diagnostic manual last published by the American Psychiatric Association in 2000, and used by psychiatrists, psychologists, and other behavioral health care workers to help diagnose and treat patients. ${ }^{148}$

142 Tax expenditures are defined in the law as " "revenue losses attributable to provisions of the Federal tax laws which allow a special exclusion, exemption, or deduction from gross income or which provide a special credit, a preferential rate of tax, or a deferral of liability.", Executive Office of the President of the U.S., Analytical Perspectives, Budget of the United States Government, Fiscal Year 2007, at 285 (2006) (noting that tax deductible employer contributions to medical insurance premiums and tax-free insurance reimbursements for employees' medical care is estimated to be about 900 million dollars from 2007-2011).

143 Pear, supra note 131.

144 Id.

145 Bruce Josten, Executive Vice President for Government Affairs, complained that the House version of the bill would "constrain employers' flexibility in plan offerings, and ultimately, cause employers to cut or curtail voluntary benefit offerings." Kevin Diaz, House to Vote on Cause Wellstone Championed, STAR TrIB., Mar. 5, 2008, at A9. To pressure Congress, he threatened to count House members' votes in the chamber's annual ratings scorecard. Id.

146 H.R. 1424, 110th Cong. § 512 (c)(2) (2008) (enacted).

147 Am. Psychiatric Ass'n, Diagnostic and Statistical Manual of Mental DisorDERS (4th ed. 2000).

148 Id. at xxiii. 
Although federal employees and members of Congress have insurance programs mandating coverage for all illness listed in the DSM, ${ }^{149}$ business leaders strongly opposed this mandate in the Wellstone Act because this meant "[b]usinesses [would] be faced with the choice of covering every single mental or substance abuse disorder listed in the diagnostic manual, or nothing at all. [And] [n]either choice [was] appealing." 150 Under the Wellstone Act, employers can choose which mental illnesses to cover in their insurance plans, versus having to insure against every DSM listing; this compromise represents a middle-ground to the unappealing "all or nothing" approach. ${ }^{151}$ Even though critics note that the DSM includes conditions such as caffeine intoxication and sleep disorders resulting from jet lag, employers may elect to exclude less controversial illnesses like eating disorders, attention deficits, and antisocial psychoses. ${ }^{152}$ Addiction treatment does not have to be covered; the law simply requires parity of benefits if it is included in the plan. ${ }^{153}$ Potentially, employers could eliminate coverage for certain significant and prominent mental illnesses, thereby making the Act's purpose null and void.

The problem arises when employers choose to arbitrarily exclude illnesses based on stereotypes, false assumptions, or costs. Employers typically overestimate the cost of providing mental health insurance. ${ }^{154}$ Based on preliminary data regarding parity coverage, the total number of mental and physical health claims should decrease, and a firm's premiums should actually drop. ${ }^{155}$ Furthermore, employers are encouraged to provide coverage because data indicates a positive correlation between behavioral insurance parity and such utilitarian measures as employee absenteeism, over-use of other physical health insurance benefits, and employee productivity. ${ }^{156}$ The effect occurs because enhanced behavioral health care creates a healthier, cheaper, and more productive workforce. ${ }^{157}$

149 See, e.g., Rush Holt, Insurance Should Cover Mentally Ill (Mar. 9, 2008), http:// www.rushholt.com/node/188 (last visited Aug. 12, 2009) ("The Paul Wellstone Mental Health and Addiction Equity Act would require that all Diagnostic and Statistical Manual of Mental Disorders illnesses be covered, rather than letting insurance companies determine their own scope of coverage. This is the same coverage requirements that we as Members of Congress receive under our federal employee health plan and our constituents deserve no less coverage").

150 E. Neil Trautwein, a Vice President of trade group National Retail Federation helped negotiate the compromise bill. Pear, supra note 131.

151 "It appears each individual group plan gets to decide WHICH mental illness to cover! No DSM definitions of mental illness are mentioned whatsoever. Can you imagine a Health plan deciding WHICH cancers or WHICH heart problems to cover?" Posting by Anonymous to NAMIblog, http://blog.nami.org/2008/03/mental-health-parity.html (Aug. 16, 2008, 14:30 EST).

152 See generally Trapp, supra note 6.

153 Id.

154 U.S. Gen. Accounting Office, Mental Health Parity Act: Despite New Federal Standards, Mental Health Benefits Remain Limited 16-18 (2000), available at http:// www.gao.gov/archive/2000/he00095.pdf ("Our findings corroborate past studies' estimates that implementing federal parity would have a negligible effect on employers' claims costs.").

155 Id.

156 See infra Part IV.B.

157 See infra Part IV.B. 


\section{Positive Effects of the New Laws}

The new laws should have at least two positive effects. First, the mandate that mental health coverage be identical to other kinds of health care coverage under the Wellstone Act, and the expansion of the ADAAA to cover the kinds of psychiatric care previously limited or excluded could minimize stereotypes about the mentally ill. Second, the laws should reduce employer costs in general.

\section{A. The New Laws Should Result in Fewer Stereotypes}

The Wellstone Act and the ADAAA both express (at least) an intent to reduce stereotypes. This section will discuss the pervasiveness of such stereotypes, their bases and detrimental effects, and provide legislative history that offers hope of change to mental health sufferers.

In 1999, the Surgeon General of the United States prepared a report on the state of mental health. ${ }^{158}$ Several authors, including the directors at the Substance Abuse and Mental Health Services Administration and the Center for Mental Health Services, wrote a foreword in a report to the Surgeon General, complaining that "despite unprecedented knowledge gained in just the past three decades about the brain and human behavior, mental health is often an afterthought and illnesses of the mind remain shrouded in fear and misunderstanding."159 At that time, estimates showed that "about $28 \%$ of the U.S. adult population in any year has a diagnosable mental or addictive disorder, yet only $8 \%$ [seek] treatment," ${ }^{160}$ in part because of stigma. ${ }^{161}$

Much of the stigma is based on misperceptions. A recent survey found that "seventy-one percent of the general population thought that mental illness resulted from an emotional weakness; sixty-five percent thought bad parenting caused mental illness; and forty-five percent thought victims of mental illness could 'will it' away." "162 Two surveys conducted by social science researchers found the public's current opinion toward mental illness more negative than public opinion over half a century ago. ${ }^{163}$ In those reports, only ten percent of the general public thought mental illness "had a biological basis or involved the brain." 164 American society heaps blame upon mental illness sufferers, per-

158 Satcher, supra note 16.

159 Id.

160 Jonathan Klick \& Sara Markowitz, Are Mental Health Insurance Mandates Effective?: Evidence from Suicides 1 (Nat'1 Bureau of Econ. Research, Working Paper No. 9994, 2003), available at http://www.nber.org/papers/w9994.

161 Charity Felts, Comment, Dealing with a Depressed Workforce: Are American Employers Doing Enough to Support the Mental Health Challenges Affecting Today's Employees?, 9 Scholar 119, 130 (2006).

162 Maria A. Morrison, Changing Perceptions of Mental Illness and the Emergence of Expansive Mental Health Parity Legislation, 45 S.D. L. REV. 8, 10 (2000).

163 Jo C. Phelan et al., Public Conceptions of Mental Illness in 1950 and 1996: What is Mental Illness and Is It to be Feared?, 41 J. Health \& Soc. Behav. 188, 197-98 (2000) (comparing survey results from 1950 and 1996 as to whether people believe the mentally ill are violent).

164 Stephen M. Stahl, Essential Psychopharmacology 136-37 \& 137 tbl.5-1 (2d ed. 2000). 
ceiving them as choosing not to control their psychological well-being. ${ }^{165}$ Many people also consider mentally ill individuals as potentially violent, regardless of studies showing the mentally ill are "no more violent than the general population." 166 According to National Alliance for the Mentally Ill, an advocacy group, eighty-seven percent of Americans state television is their "primary source of information about mental illness." 167 Mental illness stereotypes are common in American television programs: the mentally ill are portrayed as evil, psychotic killers, or ridiculed fools; mental illness is depicted as a con. ${ }^{168}$

Reduction of stigma is important because stigma causes real discrimination against the mentally ill in areas such as housing, jobs, and custody of children. A recent study concludes that stigma against the mentally ill exacerbates mental health problems, thereby impeding managements' ability to improve the workplace. ${ }^{169}$

The Wellstone Act aims to reduce stigma by normalizing mental illness. ${ }^{170}$ As Rosalyn Carter, former First Lady and mental health rights activist, summarized during House hearings on the bill, "I have always believed that if insurance covered mental illnesses it would be all right to have them. This may be the reason stigma has remained so pervasive, because these illnesses are treated differently from other health conditions." 171 The Act strives to replace stigma with compassion and sympathy. House co-sponsor Patrick Kennedy (D-R.I.) acknowledged, "[n]o one voluntarily chooses to live the kind of sordid,

165 Alison Bass, Stigma Against Mental Illness Persists Despite New Research, Hous. Chron., Feb. 16, 1992, at 3 (noting that "many Americans still hold deeply ingrained beliefs that people with schizophrenia, depression and other severe mental disease are frightening and somehow to blame for their fate"). Other countries, such as Mexico, India, and Great Britain, appear to be more tolerant of mental illness than the United States and view mental illness as something outside a person's control. Id.

166 Tom Siegfried \& Sue Goetinck, Association Between Violence, Mental Illness Disputed (1996), http://www.pendulum.org/articles/articles_dmn_violence.html ("[S]ome studies show that people with mental illness are no more violent than people in general.").

167 Donald L. Diefenbach, The Portrayal of Mental Illness on Prime-Time Television, $25 \mathrm{~J}$. Community Psychol. 289, 290 (1997).

168 In the movie Psycho, "[w]e learn at the end that "Mother" is Norman himself who developed a split personality after murdering his real mother and her lover in a fit of jealousy." IMDb, Biography for Norman Bates (Character) from Psycho (1960), http://www.imdb.com/ character/ch0003067/bio (last visited Aug. 12, 2009). For an example of people serving the mentally ill as evil, consider Hannibal Lecter, a "a brilliant psychiatrist . . . [and] cannibalistic serial killer." IMDb, Biograpy for Dr. Hannibal Lecter (Character) from The Silence of the Lambs (1991), http://www.imdb.com/character/ch0001399/bio (last visited Aug. 13, 2009).

169 See Steven F. Cyboran \& Ruth Donahue, How to Improve the Behavioral Health of an Organization, PERsPeCTIVES , Oct. 2007, http://www.sibson.com/publications/perspectives/ volume_15_issue_3/behavioral_health.html.

170 David Wellstone, son of the late Minnesota U.S. Senator, who first introduced the mental health and addiction parity bill back in 1996, called the legislation a "step into the new century" and a "first step to taking away the stigma of the people who are affected." Marisa Helms, Wellstone's Landmark Mental-Health Parity: What's Ahead for the Law, MinnPost, Oct. 7, 2008, http://www.minnpost.com/stories/2008/10/07/3797/.

171 The Paul Wellstone Mental Health and Addiction Equity Act of 2007: Hearing on H.R. 1424 Before the Subcomm. on Health, Employment, Labor and Pensions, 110th Cong. 20 (2007) [hereinafter Hearing] (statement of Rosalynn Carter, former First Lady). 
painful, destructive life [led by] . . . people who are alcoholics and addicts or people who are depressed or people who are suffering from schizophrenia or bipolar disorder [or] . . o obsessive-compulsive disorder. . . ."172

The ADAAA expresses a parallel intent, perhaps even more emphatically. The clearly stated purpose of the Act is "to carry out the ADA's objectives of providing 'a clear and comprehensive national mandate for the elimination of discrimination' and 'clear, strong, consistent, enforceable standards addressing discrimination' by reinstating a broad scope of protection to be available under the ADA." 173 Time will tell if the new laws reduce such stereotypes, but such words offer hope to millions.

\section{B. The New Laws Will Reduce Employer Costs for Mental Illnesses}

Another positive effect of the new laws is that costs to businesses should decrease. This section first discusses the cost to employers, in the billions of dollars, for providing improper mental health coverage to employees, either through direct or indirect costs. Second, the new laws, which enable businesses to provide the same benefits for mental health as for allopathic illnesses, will reduce employer costs.

Data gathered over the last two decades reflect the costliness to business in failing to provide mental health parity in employment. In 1995, lost productivity and worker absenteeism as a result of clinical depression cost American businesses $\$ 28.8$ billion annually. ${ }^{174}$ In 1996, 7.8 million workers were mentally ill, and their annual cost to businesses per employee as a result of their mental illness was $\$ 4200 .{ }^{175}$ In 1997 , employers annually paid $\$ 180$ billion as a result of presenteeism (i.e., coming to work but performing below par) and $\$ 118$ billion for absenteeism. ${ }^{176}$ Figures from 2003 highlighted workplacerelated costs of mental illnesses at approximately $\$ 70$ billion annually, stemming from absenteeism, turnover and retraining expenses, lower productivity, and increased medical costs. ${ }^{177}$ In 2007, American human resources executives ranked mental illness as having more effect on indirect costs for employers than any other health issue. ${ }^{178}$

In addition, health insurance plans not covering primary mental illness escalate employers' costs for co-morbidity conditions. Health insurance plans not covering substance abuse treatment, a common co-morbidity condition with

172 Id. at 7 (statement of Rep. Patrick J. Kennedy).

173 ADA Amendments Act of 2008, § 2(b)(1), Pub. L. No. 110-325, 122 Stat. 3553, 3554 (2008).

174 Coal. for Fairness in Mental Illness Coverage, Employers Should Support Mental Health Parity (2003), available at http://www.mhlg.org/business_3-03.pdf [hereinafter COAL. FOR FAIRNESS].

175 Id.

176 Partnership for Workplace Mental Health \& Meritian Health, The Partnership for Workplace Mental Health and Meritain Health Announce Results of EMPLOYEE SuRVEY, available at http://www.workplacementalhealth.org/partnershipMeritain HealthSurveyReport.pdf (last visited Aug. 18, 2009).

177 CoAl. FOR FAIRnEss, supra note 174.

178 Press Release, Partnership for Workplace Mental Health, HR Executives Rank Mental Illness \#1 for Effect on Indirect Costs (May 31, 2007) (available at http://www.workplacementalhealth.org/employer_resources/InnerworkingsSurveyReleasevFINAL530.pdf). 
psychiatric conditions like bipolar disorder and clinical depression, can escalate allopathic medical costs for the employer. ${ }^{179}$ Moreover, at least twenty-five percent of hospital admissions are due to alcoholism-related complications and sixty-five percent of emergency room visits are for alcohol or other drug related mental health services, thus costing the employer more, rather than less. ${ }^{180}$

The World Health Organization found that untreated mental health problems are by far the most disabling diseases, accounting for more than onefifth of all lost days of productive life. ${ }^{181}$ For example, depressed workers miss 5.6 hours per week of productivity due to absenteeism and presenteeism, compared to 1.5 hours for non-depressed workers. ${ }^{182}$ Alcohol-related illness and premature death due to alcoholism cost employers over $\$ 129.5$ billion in lost productivity per year. ${ }^{183}$

Providing the same coverage for mental health as for allopathic illness, some researchers posit, results in a lowering of indirect costs for businesses as well. ${ }^{184}$ A team of researchers recently studied the effect of increased access to mental health care. ${ }^{185}$ They reported, for example: "From the employer's perspective, enhanced depression care yields a [per capita] net cumulative benefit of $\$ 2895$ after 5 years." 186 Other studies also suggest positive results for employers. A 1998 study found that giving patients access to outpatient mental health services resulted in fewer disability claims than plans without. ${ }^{187}$ In 1999, a four-year study of a plan providing mental health coverage yielded a four-to-one return on investment after considering absenteeism, turnover, and medical claims. ${ }^{188}$ In 2000 , one company reported a 48.9 percent decrease in medical and surgical costs as a result of providing mental health counseling. ${ }^{189}$

Cost benefit analyses support the conclusion that tangible economic and productivity returns further justify parity in mental health benefits. One study concluded employers net a "potentially meaningful return on investment from enhanced depression treatment" from providing mental health coverage, especially in firms that rely on "team production, expensive substitute labor, and/or

179 Yehuda Sasson, Miriam Chopra, Eran Harrari, Keren Amitai \& Joseph Zohar, Bipolar Comorbidity: From Diagnostic Dilemmas to Therapeutic Challenge, 6 InT'L J. NeuroPSYCHOPHARMACOLOGY 139, 139-44 (2003) ("There is convincing evidence that rates of substance use and anxiety disorders are higher among patients with bipolar disorder compared to their rates in the general population. The interaction between anxiety disorders and substance use goes both ways: patients with bipolar disorder have a higher rate of substance use and anxiety disorder, and vice versa."). See generally John V. Jacobi, Parity and Difference: The Value of Parity Legislation for the Seriously Mentally Ill, 29 Am. J.L. \& Med. 185 (2003).

180 Sasson, supra note 179 at 142.

181 Hearing, supra note 171, at 10 (statement of Rep. Patrick J. Kennedy).

182 Id.

183 Id

184 Nat'l Advisory Mental Health Council, Healthcare Reform for Americans with Severe Mental Illnesses: Report of the National Advisory Mental Health Council, 150 Aм. J. PsYCHIATRY 1447, 1457 (1993).

185 Philip S. Wang et al., The Costs and Benefits of Enhanced Depression Care to Employers, 63 Archives Gen. Psychiatry 1345 (2006).

186 Id. at 1345.

187 COAL. FOR FAIRnESS, supra note 174.

188 Id.

189 Id. 
output shortfall penalties; and low turnover rates." 190 As discussed above, "[e]vidence is mounting that worker depression may have its greatest impact on productivity losses, including increased absenteeism and short-term disability, higher turnover, and suboptimal performance at work." ${ }^{191}$ By providing mental health parity, the new laws will dramatically improve cost benefits for employers. ${ }^{192}$

It is no surprise then that some employer and insurance groups supported the new parity law in the Wellstone Act. ${ }^{193}$ Businesses assert they are willing to coordinate physical and mental health management. ${ }^{194}$

\section{Conclusion}

From the time of Elijah, the mentally ill have suffered stigma. Imagine a company that could refuse to hire a woman, train a Latino, or promote an Evangelical. Then remember that, most often, under the original ADA and Sutton, such discrimination against the mentally ill was tolerated, or even sanctioned. Conceptualize an insurance policy limiting heart patients to one hospital stay per year, or excluding care for lung cancer patients because their personal weakness to smoke contributed to their ill health. Then remember that arbitrary limits on mental health treatment and benefits were commonplace before the Wellstone Act. The potential loss of talents of those with mental illness but without financial resources to society is both inefficient and unjust. ${ }^{195}$ Last year, while Congress debated the amendment, Rosalyn Carter excoriated Congress: "[I]t is unconscionable in our country and morally unacceptable to treat 20 percent of our population ... . . . as though they were not worthy of care ... [t]hen we pay the price for this folly in homelessness, lives lost, families torn apart, loss of productivity. ${ }^{196}$

Put simply, Congress was right to enact both the ADAAA and the Wellstone Act. The benefit of assuring employees they need not hide their mental illnesses and can afford to receive psychiatric treatment suggests that social practices must be judged without regard to their economic efficiency. Good will and faith in the current workforce has its own intrinsic value. The ADAAA and the Wellstone Act bring the mentally ill a more expansive definition of

190 Anthony T. Lo Sasso, Kathryn Rost \& Arne Beck, Modeling the Impact of Enhanced Depression Treatment on Workplace Functioning and Costs: A Cost-Benefit Approach, 44 Med. Care 352, 356-57 (2006).

191 Ron Z. Goetzel et al., The Business Case for Quality Mental Health Services: Why Employers Should Care About the Mental Health and Well-Being of Their Employees, $44 \mathrm{~J}$. Occupational \& Envtl. Med. 320 (2002).

192 See Cyboran \& Donahue, supra note 169 ("Reduc[ing] spending on behavioral health services [as] a cost-cutting tactic eventually backfires by causing an increase in overall healthcare expenditures.").

193 Alison Bell, Experts: New Parity Law May Not Cause Severe Employer Anxiety, NAT'L Underwriter Life \& Health, Nov. 2008, at 48, 48.

194 Id.

195 According to Mike Faenza, President of the National Mental Health Association, an advocacy organization for patients and professionals: "[T]he bottom line is that people with mental illnesses are the last [remaining] class of American citizens that are blatantly discriminated against in any social institution." Of Sound Mind and Body, supra note 18.

196 Hearing, supra note 171, at 17-18 (statement of Rosalynn Carter, former First Lady). 
disability and business a stronger bottom-line. Myths and stereotypes die hard, and the current economic climate may lead to less health insurance in the workplace. Although there are many steps left to take, the ADAAA and Wellstone Act bring us one step closer to achieving mental health parity. 